P-ISSN: 2541-6960; E-ISSN: 2549-8754

Yupa: Historical Studies Journal

Vol. 4 No. 2, 2020 (62-72)

http://jurnal.fkip.unmul.ac.id/index.php/yupa

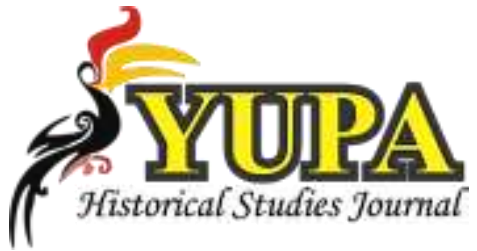

\title{
Revolusi di Tanah Alas: Peranan Masyarakat dalam Mempertahankan Kemerdekaan Indonesia Tahun 1945-1950
}

\author{
Halimah$^{1}$, Suprayitno ${ }^{2}$, Warjio ${ }^{3}$ \\ 1Universitas Sumatera Utara, Aceh, Indonesia \\ 2 Universitas Sumatera Utara, Medan, Indonesia \\ 3 Universitas Sumatera Utara, Medan, Indonesia \\ 1halimahselian6@gmail.com, 2nisanaceh@gmail.com, 3warjio1974@gmail.com
}

\begin{tabular}{ccc}
\hline Received & Accepted & Published \\
$02 / 09 / 2020$ & $12 / 10 / 2020$ & $31 / 12 / 2020$ \\
\hline
\end{tabular}

\begin{abstract}
Research has been carried out on the Revolution in the Alas Land and the Role of the Society in Defending Indonesian Independence at the time the revolution took place. In this study using historical methods to reconstruct it, which consists of four stages, including heuristics, criticism, interpretation, and historiography. The results of this study indicate that the revolution in Tanah Alas was not only pioneered by people who fought physically. In addition, there are a majority of people who have contributed to the preparation of the war, both in terms of providing equipment and food needs. The Physical Revolution period in Alas land involved many figures and people of the Land of Alas. Apart from participating in physical warfare, they also persistently helped meet the needs of war fighters. Thus, it can be said that this society has a very important role in maintaining the independence of Indonesian Republic during the revolution.
\end{abstract}

Keywords: East Sumatera, South East Aceh, Revolutionary War, Society of Alas, Tanah Alas, The Role of The Community.

\begin{abstract}
Abstrak Telah dilakukan penelitian mengenai Revolusi di Tanah Alas dan Peranan Masyarakatnya dalam Mempertahankan Kemerdekaan Indonesia pada saat revolusi tersebut berlangsung. Dalam penelitian ini menggunakan metode sejarah untuk merekonstruksinya, yang terdiri dari empat tahap, diantaranya heuristik, kritik, interpretasi, dan historiografi. Hasil penelitian ini menunjukkan bahwa revolusi di Tanah Alas tidak hanya di pelopori oleh masyarakat yang ikut berperang secara fisik. Selain itu terdapat mayoritas masyarakat yang memiliki andil dalam persiapan perang tersebut, baik dari segi penyediaan peralatan sampai dengan kebutuhan pangan. Masa Revolusi Fisik di tanah Alas banyak melibatkan tokoh dan rakyat Tanah Alas. Selain ikut serta dalam perang fisik, mereka juga dengan gigih membantu memenuhi kebutuhan para pejuang perang. Sehingga, dapatlah dikatakan bahwa masyarakat ini mempunyai peranan yang sangat penting dalam rangka mempertahankan kemerdekaan R.I pada masa revolusi.
\end{abstract}

Kata kunci: Sumatera Timur, Aceh Tenggara, Perang Revolusi, Masyarakat Alas, Tanah Alas, Peran Masyarakat. 


\section{PENDAHULUAN}

Revolusi kemerdekaan Indonesia (1945-1949) merupakan salah satu periode penting dalam sejarah, hal ini disebabkan oleh karena perjuangan dalam periode ini sangat menentukan Negara Indonesia yang merdeka dan berdaulat. Perjalanan revolusi di Indonesia merupakan proses peristiwa-peristiwa perlawanan dengan senjata yang dimulai pada bulan Agustus 1945 dan berakhir pada bulan Desember 1949. Revolusi di Tanah Alas merupakan bagian dari Revolusi Nasional yang menunjukkan kegigihan perjuangan masyarakat Aceh untuk mempertahankan tanah air Indonesia dari serbuan militer Belanda.

Pada awal Revolusi Kemerdekaan daerah Tanah Alas merupakan salah satu kewedanan daerah Aceh Tengah yang ibukotanya terletak di Takengon. Selama aksi militer Belanda Pertama dan Kedua, perjuangan rakyat Aceh lebih diarahkan ke Medan Area di daerah Sumatera Timur, berhubung karena daerahnya sendiri pada saat itu tidak diduduki oleh Belanda. Pada masa Revolusi di Indonesia Tanah Alas menjadi tempat penampungan para pengungsi, khususnya yang berasal dari Sumatera Timur.

Wilayah Sumatera sampai ke Tanah Karo sudah dikuasai oleh Belanda maka Pasukan Batalion Resimen I yang dipimpin oleh Jamin Ginting dari Berastagi beserta seluruh pasukannya mengundurkan diri ke Tanah Alas yang bermarkas di Lawe Dua melalui Lawe Kesumat, Gunung Sinabung dan Tiga Binanga. Bukan hanya itu, Penduduk dari daerah-daerah yang telah diduduki Belanda saat itu juga banyak yang mengungsi ke wilayah ini. Menurut catatan resmi pemerintahan Daerah Kutacane yang di dapat dari BPS (Aceh Tenggara dalam Angka 1986), jumlah orang-orang yang mengungsi pada saat itu sebanyak lebih kurang 30.000 jiwa. Termasuk didalamnya terdapat beberapa sibayak (Raja) dari Tanah Karo, seperti Ngerajai Meliala, Raja Kelolong, dan Nerus Ginting.

Saat ini, Tanah Alas lebih dikenal dengan nama Kutacane sebagai ibukota Kabupaten Aceh Tenggarayang resmi dibentuk Pemerintah menjadi sebuah Kabupaten di Propinsi NAD (Nanggroe Aceh Darussalam) pada tahun 1974 lalu. Salah satu etnis yang bermukim di Kutacane adalahSuku Alas. Sedangkan Daerah Alas ini sendiri lebih dikenal masyarakat Alas dengan nama Tanah Alas.

Berbeda dengan daerah-daerah yang ada di Aceh pedalaman yang sebagian didiami oleh satu etnis saja yakni suku Gayo yang mendiami Takengon, Gayo Lues dan Bener Meriah. Di Tanah Alas terdapat masyarakat yang multikultural yakni didiami oleh lebih dari satu suku, Suku Alas sebagai suku terbesar dan di ikuti oleh suku Singkil, Aceh, Karo, Batak, Gayo, Jawa, Minangkabau, dan Suku Anak Jame. Tanah Alas memiliki masyarakat yang majemuk tetapi 
hampir tidak ada terdengar sama sekali kerusuhan yang melibatkan sara (suku, agama, dan ras), masyarakatnya mampu menjaga perdamaian sampai saat ini. Karena mereka diikat oleh ikatan keislaman yang kuat, sehingga budaya mereka identik dengan budaya islam. Sehingga dari dasar-dasar itu pula potensi-potensi konflik budaya dalam masyarakat dapat teratasi dengan baik. Hal tersebut diatas menggambarkan bahwa Suku Alas adalah sekelompok masyarakat yang sangat terbuka dalam menerima para pendatang dari berbagai suku dan golongan yang berbeda.

Pada masa Revolusi, daerah Tanah Alas menjadi sebuah daerah pertahanan yang sangat berperan dalam menampung rakyat yang daerahnya telah dikuasai kembali oleh Militer Belanda. Tanah Alas memiliki sumber daya alam yang memadai dari segi ekonomi sebagai penghasil pangan terutama beras dan secara geografi, daerah ini sangat strategis sebagai tempat pengumpul dan gudang distribusi. Hal ini menjadi syarat bagi rakyat Alas untuk melakukan perannya dalam membantu rakyat pendatang dan ikut serta melakukan perlawanan terhadap pasukan Militer Belanda. Semenjak itu Tanah Alas menjadi basis pertempuran menghadapi Belanda di Sumatera Timur bagian Tanah Karo-Aceh. Seluruh kegiatan perlawanan diatur dari wilayah ini, baik dari bidang tempur maupun logistik yang ditempatkan di daerah perbatasan, Lawe Kesumat di bawah pimpinan Letnan I Sahadat.

Berhubung karena arus pengungsi tak dapat dibendung maka alat-alat pemerintahan/pertahanan dalam bidang pengamanan sangat meningkat. Untuk menangani masalah ini maka diciptakanlah beberapa alternatif sebagai pertahanan kehidupan rakyat seperti membuka areal sawah dan perladangan sebagai bahan makanan, membangun kilang kayu dan kilang minyak, membangun rumah sakit, dll.

Suatu revolusi tidak akan terjadi begitu saja. Revolusi terjadi karena munculnya kekuatan-kekuatan dan cita-cita yang telah lama tertekan dan terpendam dari dalam diri masyarakat, sehingga hal ini sering disertai dengan kemarahan dan keganasan. Revolusi 1945 digerakkan oleh kekuatan-kekuatan dan cita-cita yang telah berkembang selama pergerakan kebangsaan sejak permulaan abad ke 20 yang telah memperoleh sifat-sifat yang lebih militan selama tahun-tahun kependudukan Jepang.

Berdasarkan penjelasan di atas maka penelitian ini akan berfokus untuk mengkaji pada peranan-peranan apa saja yang dilakukan oleh masyarakat Tanah Alas dalam mempertahankan dan memperjuangkan kemerdekaan di Tanah Alas pada masa revolusi.

\section{METODE}


Dalam menulis peristiwa sejarah pada masa lampau yang direalisasikan dalam bentuk penulisan sejarah (historiografi), tentu harus menggunakan metode sejarah. Metode sejarah adalah sekumpulan prinsip dan aturan yang sistematis yang dimaksudkan untuk memberikan bantuan secara efektif dalam usaha untuk mengumpulkan bahan-bahan bagi sejarah, kemudian menilainya secara kritis untuk selanjutnya menyajikannya dalam suatu sintesa dari hasilhasilnya yang biasanya dalam bentuk tulisan.

Gilbert J. Garraghan (dalam Abdurahman, 2007, hlm. 53) mengemukakan bahwa metode penelitian sejarah adalah seperangkat aturan dan prinsip sistematis untuk mengumpulkan sumber-sumber sejarah secara efektif, menilai secara kritis, dan mengajukan sintesis dari hasilhasil yang dicapai dalam bentuk tertulis. Maka dari itu, dapat disimpulkan bahwa metode penelitian sejarah adalah kegiatan pemecahan masalah dengan mengumpulkan sumber-sumber sejarah yang relevan dengan permasalahan yang akan dikaji untuk memahami kejadian pada masa lalu kemudian menguji dan menganalisa secara kritis dan mengajukan sintesis dari hasil yang dicapai dalam bentuk tertulis dari sumber sejarah tersebut untuk dijadikan suatu cerita sejarah obyektif, menarik dan dapat dipercaya.

Secara umum metodologi penelitian dalam bidang sejarah, yaitu heuristik, kritik, interpretasi, historiografi. Sumber yang akan dikumpulkan adalah sumber-sumber yang berkaitan dengan penelitian yang akan ditulis sehingga akan diseleksi dan dianalisis data mana yang sesuai dengan penelitian yang akan dibahas dan ditulis.

Pada tahap pertama (heuristik) merupakan tahap pencarian atau pengumpulan data menggunakan metode, yaitu pengumpulan data melalui penelitian kepustakaan (library research), arsip dan penelitian lapangan (field research) dan melakukan wawancara. Studi pustaka diperoleh dari sumber-sumber yang berhubungan dengan penelitian, seperti buku, jurnal, skripsi, tesis, dan disertasi. Dalam hal ini, peneliti memperoleh sumber dari perpustakaan Universitas Sumatera Utara, Perpustakaan Daerah Sumatera Utara, Perpustakaan Aceh Tenggara, BPNB (Badan Pelestarian Nilai Budaya), dan Perpustakaan Tengku Luckman Sinar. Penelitian kepustakaan dilakukan dengan tujuan memperoleh data tertulis. Dengan telaah semacam ini seyogyanya dapat dijadikan sebagai perbandingan atau tolak ukur terhadap bahan yang diperoleh dilapangan. Pengumpulan data dengan penelitian lapangan dilakukan dengan kajian penulisan, mengunjungi situs-situs sejarah yang berkaitan dengan penelitian, melakukan penelusuran langsung ke daerah penelitian yaitu Kutacane dan melakukan wawancara terhadap beberapa informan khususnya informan yang pernah mengalami secara langsung revolusi fisik yang terjadi di Kutacane, yang mengetahui bagaimana situasi masyarakat dan wilayahnya pada masa revolusi fisik.

Setelah mengumpulkan sumber, tahap kedua ialah tahap kritik sumber, untuk mendapatkan faktor kebenaran, keaslian data ataupun fakta yang diperoleh. Dalam tahapan ini, 
penulis melakukan proses persiapan penelitian dengan membaca secara kritis terhadap sumber-sumber yang telah terkumpul untuk mencari dan mendapatkan keaslian sumber tersebut baik dari segi material maupun substansinya. Kemudian melakukan kritik intern dan kritik ekstern. Kritik ekstern menentukan bahwa dokumen yang kita hadapi adalah dokumen yang kita cari, kemudian kritik intern bahwa kesaksian yang diberikan oleh sumber memang dapat dipercaya. Crosscheck adalah satu hal yang dapat digunakan untuk mendapatkan kevalidan data. Dengan demikian, penulis akan mendapat wawasan dan pehaman yang baik untuk menulis sebagai pedoman penelitian sejarah.

Setelah pengujian dan analis data dilakukan, maka tahap ketiga adalah tahap interpretasi. Dalam tahap ini, data-data yang telah diperoleh pada tahap sebelumnya akan dianalisa oleh penulis untuk menghasilkan sebuah sintesis dari objek yang penulis teliti. Objek kajian yang cukup jauh kebelakang memuat tahap interpretasi menjadi sangat vital. Berbagai fakta yang lepas satu sama lain harus dirangkaikan dan dihubungkan menjadi satu kesatuan yang selaras dan masuk akal. Tidak semua fakta dapat dimasukkan karena yang diambil hanyalah yang relevan.

Pada tahap terakhir (historiografi) merupakan tahapan sintesis yang telah diperoleh dijabarkan secara kronologis dan sistematis. Dalam hal ini, aspek kronologis menjadi perhatian utama penulis termasuk penulisannya yang harus sistematis. Pada tahap ini, penulis menjabarkan secara kronologis dan sistematis fakta-fakta yang diperoleh agar menghasilkan tulisan yang ilmiah dan bersifat objektif.

\section{HASIL DAN PEMBAHASAN}

\section{Tanah Alas Pada Masa Revolusi}

Tanah Alas merupakan sebuah wilayah yang terdapat di Lembah Alas, Provinsi Aceh. Daerah Tanah Alas tepat berada di tengah-tengah daerah Aceh di dataran tinggi gugusan pegunungan Bukit Barisan di bagian ujung pulau Sumatera. Daerah ini menjadi benteng strategis dan juga merupakan benteng terakhir bagi rakyat Aceh.

Setelah berakhirnya masa kolonial Belanda, diteruskan dengan masa pendudukan Jepang (1942-1945). Ketika itu tidak ada yang berubah dalam hal batasan wilayah, hanya saja ada sedikit perubahan nama dalam sistem pemerintahan misalnya seperti Onder Afdeeling di ganti menjadi Gun dan Lanscap diganti menjadi Sun. (Sejarah Daerah Nusa Tenggara Timur, 1977).

Pada masa revolusi, Tanah Alas menjadi sebuah Kewedanan di Kabupaten Aceh Tengah. Kabupaten Aceh Tengah masa itu terbagi menjadi tiga kewedanan, yakni: Kewedanan Takengon, Kewedanan Tanah Alas, dan Kewedanan Gayo Lues. Dalam Kewedanan Tanah Alas terdapat dua kejurunen, yakni; kejurunan Pulonas yang batasanya dimulai dari bagian Tenggara kota Tanah Alas sampai ke Meluak due dan Kejurunen Bambel di mulai dari Selatan kota Tanah 
Alas sampai ke lawe pakam. Ibukota Kewedanan Tanah Alas adalah Kutacane, tepatnya berada di wilayah kutacane lama sekarang yang juga sebagai pusat pemerintahan pada saat itu.

Menjelang revolusi di Tanah Alas, kedua daerah kejurun di Tanah Alas rakyatnya tidak pernah mau menyerah kepada Belanda dan selalu menentang apabila Belanda ingin kembali menguasai Negeri ini, hal ini disebabkan oleh karena dasar prinsip larangan agama Islam untuk tidak menyerah kepada kaum kafir.

\section{Proklamasi kemerdekaan di Tanah Alas}

Ketika berita kemerdekaan Republik Indonesia terdengar di Tanah Alas dengan cara perlahan dan terbatas karena pemerintahan pendudukan Jepang yang dipimpin oleh Gunseikanbu dan Gunyaksu masih berkuasa dan berjalan seperti biasa. Berita tidak resmi itu diterima dari Bireuen setelah Abdul Muluk melihat semangat masyarakat Jeumpa menyambut kemerdekaan. Beliau segera kembali ke Takengon dengan mengendarai Chevrolet untuk memastikan kebenaran berita tersebut.

Tepat pada tanggal 4 oktober 1945 dilakukan Upacara pengibaran bendera merah putih serta pengumuman dan pembacaan teks proklamasi di halaman kantor pengadilan. Upacara ini dipelopori oleh R.R. Rajat, Abdul karim, Ginot, Gido bangko, Kabar Ginting, dll. Kemudian dihari yang sama juga diadakan rapat pembentukan KNI (komite Nasional Indonesia) wilayah Tanah Alas dan Gayo Lues. Kemudian untuk lebih meratakan pengibaran bendera Merah Putih sampai ke pelosok-pelosok desa dan untuk memperingati dua bulan proklamasi kemerdekaan, tanggal 13 Oktober 1945 Komite Nasionl Indonesia (KNI) Daerah Aceh, melalui maklumat No.2 secara resmi memerintahkan pengibaran bendera merah Putih sampai tanggal 17 oktober pada tiaptiap rumah diseluruh daerah aceh. (Peranan Agama Islam Dalam Perang Aceh, 1976.)

Pada awal masa kemerdekaan tahun 1945, Tanah Alas masih berstatus sebagai satu keresidenan otonom yang berpusat pada provinsi Sumatera Utara yang berkedudukan di Pematang Siantar. daerah Tanah Alas pada masa itu merupakan bagian dari Propinsi Sumatera. Dan pelaksanaan pemerintahan Republik Indonesia di Aceh, mulai resmi berjalan setelah Teuku Nyak Arief pada tanggal 29 September 1945, diangkat sebagai Residen Republik Indonesia yang pertama untuk Daerah Aceh, serta Teuku Muhammad Ali Panglima Polem (anak Panglima Polem Muhammad Daud, pejuang terkenal pada akhir abad ke XIX dan awal abad ke XX), sebagai Wakil Residen, yang diangkat oleh Gubernur Sumatera Mr. TM Hasan. (Medan Area Mengisi Proklamasi, 1976.)

\section{Gambaran Perjuangan Rakyat masa Revolusi}

Gerakan perlawanan rakyat sangat terlihat beberapa saat setelah peristiwa proklamasi disiarkan. Semangat perlawanan di Tanah Alas menimbulkan gerakan massa yang bergerak untuk merebut gudang senjata dan pabrik-pabrik yang masih dikuasai Jepang dengan mengibarkan Bendera Sang Saka Merah Putih, baik di kantor-kantor yang masih dikuasai oleh 
Jepang, maupun di tempat-tempat umum lainnya. Kemudian disusul dengan pembentukan Keresidenan Aceh beserta kewedanannya Tanah Alas juga pembentukan Komite Nasional (KNI) di daerah Aceh, yaitu pada akhir Agustus sampai dengan awal Oktober 1945. Selain itu, sejak berita proklamasi kemerdekaan diterima di Tanah Alas, para pemimpin perjuangan pun segera mengambil langkah untuk memperkuat organisasi kemiliteran yang sebelumnya sudah terbentuk di daerah pusat (keresidenan Aceh), baik kesatuan tentara resmi pemerintah R.I. di sana yaitu: API (Angkatan Pemuda Indonesia atau Angkatan Perang Indonesia), kemudian menjadi TKR yang resmi dilantik oleh residen Aceh pada tanggal 12 Oktober 1945, maupun kesatuan-kesatuan kelasyakaran, yaitu Barisan Mujahidin, Pesindo dan lain-lain.

Pada masa Agresi militer I tepatnya pada tahun 1947 jumlah pengungsi sangat banyak datang ke Tanah Alas, sehingga dapat dikatakan separuh dari jumlah penduduk adalah pengungsi dari kota Medan, Dairi, Langkat, Tapanuli dan Tanah Karo. Akibat dari perjanjian tersebut mengakibatkan masyarakat dan tentara dari seluruh kesatuan Resimen-I maupun Laskar Rakyat dari berbagai daerah mundur ke daerah ini. Seperti yang di ketahui Tanah Alas merupakan daerah yang berbatasan langsung dengan Tanah Karo yang menjadi batas akhir dari wilayah Republik Indonesia dengan daerah kekuasaan Belanda berdasarkan dari beberapa perjanjian maupun perundingan seperti Linggarjati 1947 dan Renville 1948 yang telah dilakukan oleh kedua belah pihak.

Pada akhir bulan September 1947, Markas Resimen-I yang dipimpin oleh Jamin Ginting dipindahkan ke Lawe dua (Tanah Alas). Dimana pada saat itu Titi Laulisang (Tanah Karo) sudah di bumi hanguskan. Sepanjang perbatasan antara Tanah Karo dan Tanah Alas dibangun basisbasis pertahanan seperti menempatkan batalyon dari Resimen-I, ranjau darat dan pos-pos penjagaan di sekitar perbatasan antara Tanah Karo dan Tanah Alas agar Belanda tidak dapat menerobos ke Tanah Alas. Sehingga Tanah Alas Sebagai Markas Resimen IV yang Pada tanggal 27 Maret dipindahkan ke macan kumbang sebagai Resimen rimba raya (R3) menjadi daerah pertahanan terakhir dan juga sebagai daerah modal bagi Republik Indonesia. (Suprayitno, dalam Biografi Pahlawan Nasional Djamin Gintings)

\section{Kontribusi Masyarakat Alas Masa Revolusi 1945-1950 Terhadap Kemerdekaan R.I}

Pada masa Revolusi Kemerdekaan, kelompok wanita di kalangan masyarakat Alas berperan aktif mendukung kaum pria dalam berjuang menegakkan Kemerdekaan Indonesia. Diantara peranan mereka adalah memberikan bantuan dalam bidang logistik (bahan makanan) dan informasi militer kepada pasukan TNI. Bahkan pada kasus-kasus tertentu mereka menjadi pelopor dan pemimpin perjuangan. Bantuan mereka terasa sangat penting mengingat masalah logistik dan informasi tentang kondisi militer pasukan Belanda sangat menentukan jalannya operasi militer itu sendiri. 
Dalam menghadapi perang Revolusi di Tanah Alas, Masyarakat bertugas memberikan bantuan kepada laskar-laskar yang ikut berperang ke medan perang. Kalangan masyarakat Alas rela berkorban harta dan bendanya demi untuk dapat mengusir penjajahan dari bumi indonesia terutama di daerah Tanah Alas. Salah satu bentuk bantuan yang diberikan oleh masyarakat Alas adalah berupa makanan, makanan ini di siap kan oleh kaum wanita. Ada makanan dalam bentuk mentah dan yang belum di olah dan ada pula berupa makanan yang sudah diolah atau di masak.

Barang-barang atau benda yang diberikan masyarakat alas kepada para pejuang yang ikut berperang ke medan tempur tersebut tidak pernah sama sekali di paksa oleh siapapun, bahkan dianjurkan oleh sebahagian masyarakat Alas sendiri atau anjuran dari tokoh-tokoh pembesar adat. Kegiatan seperti itu memang dilakukan masyarakat secara ikhlas dan suka rela membantu para pejuang. Masyarakat senantiasa siap sedia memberikan bantuan dan pertolongan serta akan segara hadir dimanapun terjadinya perang secara tiba-tiba.

Perang Sabil bagi Orang Alas juga lazim disebut sebagai Perang Belanda dan Perang Kaphe. masyarakat Alas pun terkenal sebagai penduduk yang mencintai dan mentaati agamanya. Dalam pertentangan dengan Belanda pada masa yang lalu. Ulama-ulama mengambil bagian yang terpenting dan pidato yang diucapkan oleh panglima-panglima ulama ini dalam peperangan yang terkenal itu, adalah senantiasa berdasar atas agama; agama mana, katanya, mewajibkan setiap muslimin mengambil bagian dalam perlawanan terhadap Belanda, peperangan mana adalah "perang sabil" oleh karena yang mereka perangi adalah "kafir".

Hal-hal yang demikian jelas menunjukkan bahwa memang masyarakat Alas sangat gigih dalam membantu masyarakat yang daerahnya sudah dikuasai Belanda pada saat itu namun tetap ingin bergerilya melawan militer Belanda. Selain itu, salah satu faktor yang sangat mendukung adalah letak wilayah Tanah Alas yang sangat strategis dan yang paling penting pada masa revolusi, wilayah Tanah Alas yang belum terkuasai oleh Belanda.

Oleh karena muncul rasa kecintaan terhadap Negara beserta seluruh wilayah bagiannya sehingga membentuk keinginan untuk bebas dari kekuasaan orang asing yang telah siap kembali menjajah Bumi pertiwi. Terutama Tanah Alas sebagai "tuan rumah" dan bagian dari mereka, sehingga tidak rela bila dikuasai oleh orang lain. masyarakat Alas sangat tidak setuju jika pemimpin mereka adalah orang asing yang berbeda keyakinan dengannya. Hal ini menjadi penunjang keras bagi masyarakat untuk bisa bebas dari segala penjajahan Belanda.

\section{KESIMPULAN}

Pada masa revolusi, Tanah Alas sebagai sebuah wilayah Kewedanan di Kabupaten Aceh Tengah ikut berperan dalam mempertahankan kemerdekaan Indonesia yang pada saat itu baru diperoleh. Dengan kondisi larut dalam keterpurukan dan kehidupan masyarakat yang serba 
kekurangan terutama dalam segi ekonomi, masyarakat tetap mengerahkan seluruh tenaga dan melakukan pengorbanan untuk mempertahankan dan memperjuangkan kemerdekaan tanah alas.

Seluruh masyarakat berjuang dengan porsi yang bisa mereka berikan, Seperti kelompok wanita berperan aktif memberikan bantuan dalam bidang logistik (bahan makanan) dan informasi militer kepada pasukan TNI, sebagian pemuda-pemudi ikut bertempur ke medan perang dan sebagian lagi membantu mempersiapkan keperluan perang, baik berupa alat domistik hingga keperluan anggota pemuda yang ikut berperang. Dan tidak hanya itu, masyarakat alas juga membentuk semacam kelompok dan organisasi yang membantu pertahanan kemerdekaan pada masa revolusi di Tanah Alas. Adapun organisasi yang dimaksud seperti; organisasi kemiliteran dan pembentukan laskar-laskar masyarakat di daerah Tanah Alas sendiri. Selain itu kontribusi masyarakat untuk membantu pejuang perang masa revolusi juga tampak ketika mereka memutuskan untuk tidak masuk ke dalam organisasi kemiliteran dan kelasykaran namun cenderung membantu dan mempersiapkan kebutuhan para pejuang perang dalam berperang.

Rakyat Alas dikenal sebagai rakyat yang mencintai kemerdekaan dan tidak segan-segan mengorbankan jiwanya dalam usaha mencapai kemerdekaan ini. Sejauh perjuangan dengan Belanda yang memakan waktu berpuluh tahun menunjukkan kepahlawanan mereka dalam mempertahankan kemerdekaan mereka terhadap serangan-serangan Belanda, baik kepahlawanan putera, maupun kepahlawanan puterinya. Beribu manusia baik lelaki maupun wanita, baik tua maupun muda, telah menjadi korban dalam perjuangan ini.

Mereka sangat mendukung akan gerakan revolusi fisik yang terjadi di Tanah Alas, karena watak Masyarakat Alas yang memang tidak ingin harga diri mereka direndahkan oleh musuh terutama oleh kolonial. mereka tidak ingin dijajah dan dipimpin oleh sekelompok orang yang berbeda keyakinan dengan mereka, terutama dalam segi agama dan adat yang melarang keras akan hal tersebut.

\section{REFERENSI}

Abdurahman, D. 2007. Metodologi Penelitian Sejarah. Yogyakarta: Ar-Ruzz Media.

Anderson, B. 1988. Revoloesi Pemoeda: Pendudukan Jepang Dan Perlawanan Di Jawa 19441946. Jakarta: Pustaka Sinar Harapan.

Bakar, B. 1979. Sejarah dan Sejarawan dan Masa Depan. Prisma No. 7. Jakarta: LP3ES.

Gintings, D. 1964. Bukit Kadir. Jakarta: CV Umum.

Gintings, D. 1979. Titi Bambu. Jakarta: Keluarga Alm. Letjen Jamin Ginting. 
Hasjmy, A. 1976. Peranan Agama Islam Dalam Perang Aceh Dan Perjuangan Kemerdekaan Indonesia. Medan : Panitia Seminar Perjuangan Aceh Sejak 1873 Sampai Kemerdekaan Indonesia.

Ismail, M.G. 1994. Kasus Darul Islam di Aceh. Jakarta: Depdikbud.

Jakobi, A.K. 1998. Aceh Dalam Perang Mempertahankan Proklamasi Kemerdekaan 1945-1949: Dan Peranan Teuku Hamid Azwar Sebagai Pejuang. Jakarta: Gramedia Pustaka Utama.

Joesoef, H. 1971. Sedjarah Perdjuangan Pemuda Di Daerah Atjeh. Warta Pendidikan Dan Kebudajaan. No 7.

Kartodiharjo, S. 1975. Sejarah Nasional Indonesia. Jilid III. Depdikbud: Jakarta.

Kementerian Penerangan R.I. 1953. Republik Indonesia Propinsi Sumatera Utara. Djakarta: Keterangan dan Djawaban Pemerintah Tentang Peristiwa Daud Beureueh.

Kementerian Peneranngan R.L. 1954. Pendapat Pemerintah Mengenai Laporan Panitia DPR-RI Tentang Keadaan Di Atjeh. Djakarta.

Kelompok Kerdja SAB. 1964. Sedjarah Singkat Perdjuangan Bersendjata Bangsa Indonesia. Staf Angkatan Bersendjata.

Kuntowijoyo. 1994. Metodologi Sejarah. Yogyakarta: Tiara Wacana.

Menjambut Konperensi Muhammadijah Wilajah Daerah Istimewa Atjeh. 1962. Kutaradja: Panitia Konperensi Muhammadijah Daerah Istimewa Atjeh ke 26.

Meuraxa, D. tanpa angka tahun. Atjeh 1000 Tahun dan Peristiwa Teungku Daud Beureueh Cs. Medan: Pustaka Masmar.

Nasution, A.H. 1977. Sekitar Perang Kemerdekaan Indonesia. Bandung: Angkasa.

Nasution, A.H. 1970. Tentara Nasional Indonesia I. cetakan ketiga. Djakarta : Seruling Masa.

Panitia Pusat Peringatan Lahirnja Pemerintah Darurat, R.L. 1969. Beberapa Tjatatan Tentang : Lahirnja Tugas Dan Perdjuangan Pemerintah Darurat Republik Indonesia.

Panitia. 1965. Seminar Sedjarah Perdjuangan Pemuda Indonesia. Takengon: Daerah Tk. II Atjeh Tengah.

Prima, B.S. 1976. Medan Area Mengisi Proklamasi. jilid I. Medan: Badan Musyawarah Pejuang Republik Indonesia Medan Area.

Pulungan, B.A. 1996. Perjuangan Menegakkan dan Mempertahankan Kemerdekaan Republik Indonesia di Sumatera Utara (1945-1949) Jilid II (1947-1948). Medan: Tim Khusus Perencanaan dan Pelaksana Pembangunan Tetangger.

Revolusi Desember '45 di Atjeh atau pembasmian penghianatan tanah air, Kutaradja; pemerintah RI, tt

Ramadhan, K.H. dan Jabbar, H. 1995. Sjamaun gaharu:cuplikan perjuangan di daerah modal, Jakarta: pustaka sinar harapan.

Suprayitno (ed). Biografi Pahlawan Nasional Djamin Gintings. Yogyakarta: Penerbit Ombak.

Talsya, T. dan Basyah, A. 1969. 10 Tahun Daerah Istimewa Atjeh. Banda Atjeh: Pustaka Putroe Tjanden. 
Sedjarah dan Dokumen-dokumen pemberontakan di Atjeh. Tanpa angka tahun. Djakarta: Kesuma.

Sejarah Daerah Nusa Tenggara Timur. 1977. Proyek Penelitian dan Pencetakan Kebudayaan Daerah.

Van de Velde, J.J. 1987. Surat-Surat dari Sumatra: 1928-1949. Jakarta: Pustaka Azet. 